\title{
Two entomophagous isolated from Sumatera Utara; potential as biocontrol agent againts nematode
}

\author{
Liana Dwi Sri Hastuti ${ }^{1}$, Jane Nicklin ${ }^{2}$ and Ameilia Zuliyanti Siregar ${ }^{3}$ \\ ${ }^{1}$ Biology Department, FMIPA, University of Sumatera Utara \\ ${ }^{2}$ Biology Department, Birkbeck University of London \\ ${ }^{3}$ Agroecotechology Department, Faculty of Agriculture, University of Sumatera Utara \\ Corresponding autors: lianadwisrihastuti@gmail.com,azsyanti@gmail.com
}

\begin{abstract}
Two species of nematophagous fungi has been isolated from Sumatera Utara soil, with an aim of harnessing their potential in the biological control of plant parasitic nematodes or animal parasitic nematodes in Indonesia, especially in Sumatera Utara. Soil samples were collected from tobacco plantations, vegetable fields and ornamental plantings in the Berastagi area, and also from livestock in local farms and a dairy farm in Berastagi Area, Karo Regency. Soil also collected from un-cultivated area in Sibolangit National Park, Karo Regency. The pour method described by Larsen (1998) and the sprinkle method described by Jafee et al. (1996) were used to isolate the nematophagous fungi from soil. In this study the Chloramphenicol Water Agar Media has been used as culture media and Ceanorhabditis elegans has been used as bait. Two nematophagous fungi known as insect pathogens (entomophagous) have been isolated and determined as Lecanicillium lecanii and Paecilomyces fumosoroseus.
\end{abstract}

Key words: entomophagous, biocontrol agent, nematode, Sumatera Utara

\section{INTRODUCTION}

Entomopathogenic fungi can be found in the cultivated soil around crop plantation or un-cultivated soil in the forest (Brownbridge et al. 1993). They have been isolated from the interface between leaf litter and the organic layer of soil under ornamental plant also crop plant (Hajek et al. 2000).

According to Duddington (1955), the best source of predacious fungi is rotting vegetable matter, preferably from or near the soil. They are abundant in forest leaf - mould, and even more in rotting bark and twigs and in pieces of decomposing leaf and stem from the floor of a wood or from garden compost heap.

Inoculations of sterile agar with decaying organic matter naturally produces mixed cultures of fungi, bacteria, protozoa, nematodes and unfortunately mites, together with occasional visitors such as a moss protonemata, and even small annelids. Such a mixture is, up to point, desirable and even essential in order to supply prey for the fungi, but the danger is that predacious fungi may be completely swamped by a heavy growth of other moulds. To prevent this, a weak culture medium should be used (Duddington, 1955). Larsen (1998) suggests using water agar with chloramphenicol (CHF WA) for soil inoculation and this media has been used successfully to restrict the growth of other organism. 
According to Mérillon and Ramawat (2012), nematophagous fungi are not only parasite on the larva of insect, they also parasite and infect nematode worm in the soil. The Paecilomyces sp is the most frequently isolated; they can survive in the soil as saprophytic and more effective in infecting eggs, juvenile and female of nematode worm in the soil

In addition, Paecilomyces and Lecanicillium considered as biocontrol agent against plant parasitic nematode and the best egg colonisizer caused their parasitism on the eggs of root knot nematode especially Meloidogyne

\section{MATERIAL AND METHODS}

Random soil samples (using thrown $0.5 \mathrm{~m}$ quadrats) were taken based on Duddington (1955) observations that nematode trapping fungi can be found in the areas where the numbers of nematodes are abundant. He predicted that a large number of nematode-trapping fungi may be found in composts and soils and in the dung of herbivores where many nematodes are present.

The rhizosphere area of plants was chosen for soil sampling considering that in this zone there is a high probability that nematode-trapping fungi will be present. The rhizosphere is the narrow region of soil that is directly influenced by root secretions and associated soil microorganisms (Mitra and Zaman, 2014). Soil which is not part of the rhizosphere is known as bulk soil. The rhizosphere contains many bacteria that feed on sloughed-off plant cells, termed rhizodeposition, and the proteins and sugars released by roots. Protozoa and nematodes that graze on bacteria are also more abundant in the rhizosphere. Thus, much of the nutrient cycling and disease suppression needed by plants occurs immediately adjacent to roots (Giri et al., 2005).

Areas chosen for sampling consist of: javanica (Mérillon and Ramawat, 2012). Their ability to infect and parasite of eggs, juvenile and female of the nematode worm in the soil is potential as biocontrol agents against nematode especially in the control of plant parasitic nematodes or animal parasitic nematodes.

The aim of this study is to exploration the number species of nematophagous in Indonesia especially in Sumatera Utara followed by isolation and determine species from Sumatera Utara regarding to their potential as biocontrol agent.

1. Several different soils from crop plantations where symptoms of plant parasitic nematode infestations were evident.

2. Decayed bovine faeces from local farms and co-operatives (dairy milk company) in several areas of Sumatera Utara and Java

3. Soil samples were also taken from areas not commercially cultivated. The area of Sibolangit National Park and Bogor Botanical garden were chosen as area to take soil samples. Rifai and Cooke (1965) found 2 species of nematode trapping fungi in Bogor Botanical Garden.

\section{Maintenance of Caenorhabditis elegans}

The nematode Caenorhabditis elegans was obtained from Davies, K.G (University of Nottingham) and was used as a bait for nematode trapping fungi. C. elegans was maintained and produced in the laboratory using the method of Stiernagle (2006), either on nematode growth medium (NGM) plates to which Escherichia coli OP 50 were applied. To obtain a large quantity of nematodes, plates were supplied with $0.5 \mathrm{~g}$ peanut butter/litre media of NGM. (Wood, 1988 in Mendoza, 1999).

Before use, nematodes $(C$. elegans) as bait were washed from the 
cultures in either M9 buffer (Wood, 1988 in Mendoza 1999) or sterile distilled water. Suspensions of $C$. elegans were centrifuged and the supernatant was decanted. The pellet (approximately containing 200-500 C. elegans) was resuspended in a minimal volume of buffer or water and the worms were poured into the soil media plates or CHF-WA (Chloramphenicol Water Agar) media. All works were carried out in sterile condition.

\section{Isolation of Nematode Trapping Fungi from soil and faecal samples}

Isolation of nematode trapping fungi was by three different methods: the method of Larsen et al., (1988) Eren and Pramer (1965) and by the sprinkle technique as described by Jaffee (1996). Larson et al., (1988) method: Primary isolation of nematode-trapping fungi was achieved using Chloramphenicol-2\% water agar (CHF-WA) medium.

- A subsample of each soil sample (10g) was suspended in $50 \mathrm{ml}$ distilled water in a $250 \mathrm{ml}$ Erlenmeyer flask.

-The flasks were vigorously shaken for 30 minutes on a wrist action shaker and supernatant samples $(1 \mathrm{ml}$ each) were separately spread on the CHF-WA plates.

- For faecal samples, $2 \mathrm{~g}$ of each sample was thoroughly homogenized and directly cultured on $2 \%$ water agar plates.

- Three days after incubation at $25^{\circ} \mathrm{C}$, Caenorhabditis elegans were suspended in $0.1 \mathrm{ml}$ distilled water or M9 Buffer. Approximately 200-500 nematodes were added as bait for the nematode trapping fungi on each plate.

- The plates were maintained at $25^{\circ} \mathrm{C}$ for 2 months in order to demonstrate growth of nematophagous fungi. During this period, the plates were monitored 3-4 times a week for the presence of fungi using a light microscope and stereomicroscope. Any fungal isolates demonstrating nematode trapping fungal characteristics were sub-cultured on to
PDA until they were in pure culture, and then the fungal isolates were maintained in potato dextrose agar (PDA).

Eren and Pramer (1965) technique was also used, where $1-10 \mathrm{ml}$ of soil suspensions were added to the surface of each Petri plates containing water agar and incubated in the $25^{\circ} \mathrm{C}$ room temperature. Three days after inoculation, a suspension of 200-500 C. elegans was poured into the plates. Plates were incubated at $20 \mathrm{oC}$ and monitored 3-4 times a week for 6 weeks for nematode trapping fungi. Any fungal isolates demonstrating nematode trapping fungal characteristics were sub-cultured on to PDA until they were in pure culture, and then the fungal isolates were maintained in potato dextrose agar (PDA).

The sprinkle technique as described by Jaffee (1996) in Wachira et al. 2009 was also used. A small subsample (1g) of each soil was sprinkled on to tap water agar plates (with $0.1 \mathrm{~g} / \mathrm{L}$ streptomycin added after autoclaving). Nematode worms (a suspension of 200500 C. elegans) were added to the inoculated plate to act as bait for the nematode trapping fungi. Plates were incubated at $20^{\circ} \mathrm{C}$ and monitored 3-4 times a week for 6 weeks for nematode trapping fungi. Any fungal isolates demonstrating nematode trapping fungal characteristics were sub-cultured on to PDA until they were in pure culture, and then the fungal isolates were maintained in potato dextrose agar (PDA).

\section{Identification of nematophagous fungi}

The identification of nematophagous fungi is mainly based on morphological characters discernible through examination of the cultures by the light microscope and stereomicroscope. Fresh samples of nematode-trapping fungi were examined directly from plates or by placing agar blocks on to glass slides under light microscope. The observation of nematode trapping fungi was also followed after staining the mycelium with $1 \%$ cotton blue in lactophenol on the glass 
slides under light microscope. Staining with cotton blue clarified the morphological characteristics of nematode trapping fungi and allowed semi-permanent slides to be made. The macroscopic and microscopic characters were also measured using eye piece gratitude and calibrated using a slide micro meter (normally with 100x magnification). Macroscopic characters, such as the colony characteristic (colour, surface, structure, diameter of colony after several days of incubation), were recorded. Microscopic characters such as conidiophore characteristics (wall, septum, colour, branched or unbranched); and conidia (shape, size, diameter, number of cells, colour) were also recorded in Table 1. 
Table 1. Soil sample from Field Trip 2 indicating the date of sampling, substrate, source and location from which the sample was taken.

\begin{tabular}{|c|c|c|c|c|c|}
\hline No & DATE & SUBSTRATE & SOURCES & LOCATION & NOTE \\
\hline 1 & 09.02 .10 & Decayed faeces & Rabbit & $\begin{array}{l}\text { Medan, Sumut*, } \\
\text { ID** }\end{array}$ & Domestic Farm (DF) \\
\hline 2 & 09.03 .10 & Soil & $\begin{array}{l}\text { Rhizosphere of Nicotiana } \\
\text { tabacum (tobacco) }\end{array}$ & Helvetia, Medan & Tobacco Plantation \\
\hline 3 & 09.08 .10 & Decayed faeces & Cow & Helvetia, Medan & Tobacco Plantation \\
\hline 4 & 09.08 .10 & Decayed faeces & Sheep & Helvetia, Medan & Tobacco, Plantation \\
\hline 5 & 10.08 .10 & Decayed faeces & Horse & $\begin{array}{l}\text { Berastagi, Karo } \\
\text { Regency (KR) }\end{array}$ & Domestic Farm \\
\hline 6 & 10.08 .10 & Decayed faeces & Horse & $\begin{array}{l}\text { Berastagi, Karo } \\
\text { Regency (KR) }\end{array}$ & Commercial Farm(CF) \\
\hline 7 & 10.08 .10 & Fresh faeces & Horse & $\begin{array}{l}\text { Berastagi, Karo } \\
\text { Regency (KR) }\end{array}$ & Commercial Farm(CF) \\
\hline 8 & 10.08 .10 & Decayed faeces & Cow & $\begin{array}{l}\text { Berastagi, Karo } \\
\text { Regency }(\mathrm{KR})\end{array}$ & Commercial Farm(CF) \\
\hline 9 & 10.08 .10 & Fresh faeces & Cow & $\begin{array}{l}\text { Berastagi, Karo } \\
\text { Regency (KR) }\end{array}$ & Commercial Farm(CF) \\
\hline 10 & 10.08 .10 & Soil & $\begin{array}{l}\text { Rhizosphere of potato ( } S \text {. } \\
\text { tuberosum ) }\end{array}$ & $\begin{array}{l}\text { Berastagi, Karo } \\
\text { Regency (KR) }\end{array}$ & Domestic Farm (DF) \\
\hline 11 & 10.08 .10 & Soil & $\begin{array}{l}\text { Rhizosphere of potato }(S . \\
\text { tuberosum }) 2\end{array}$ & $\begin{array}{l}\text { Berastagi, Karo } \\
\text { Regency (KR) }\end{array}$ & Domestic Farm (DF) \\
\hline 12 & 10.08 .10 & Soil & Rhizosphere $S$. lycopersicum & $\begin{array}{l}\text { Berastagi, Karo } \\
\text { Regency (KR) }\end{array}$ & Domestic Farm (DF) \\
\hline 13 & 10.08 .10 & Soil & Rhizosphere Broccoli raab & $\begin{array}{l}\text { Berastagi, Karo } \\
\text { Regency (KR) }\end{array}$ & Domestic Farm (DF) \\
\hline 14 & 10.08 .10 & Soil & $\begin{array}{l}\text { Rhizosphere Allium fistulosum } \\
\text { (Spring onion) }\end{array}$ & $\begin{array}{l}\text { Berastagi, Karo } \\
\text { Regency (KR) }\end{array}$ & Domestic Farm (DF) \\
\hline 15 & 02.09 .10 & Soil & $\begin{array}{l}\text { Rhizosphera } \\
\text { of Pteridhophyta }\end{array}$ & $\begin{array}{l}\text { Sibolangit, Karo } \\
\text { Regency }\end{array}$ & National Park (NP) \\
\hline 16 & 02.09 .10 & Soil & Rhizosphere of Zingiberaceae & $\begin{array}{l}\text { Sibolangit, Karo } \\
\text { Regency }\end{array}$ & National Park (NP) \\
\hline 17 & 02.09 .10 & Soil & Rhizosphere of Eucalyptus & $\begin{array}{l}\text { Sibolangit, Karo } \\
\text { Regency }\end{array}$ & National Park (NP) \\
\hline 18 & 02.09 .10 & Soil & Rhizosphere of Pinus & $\begin{array}{l}\text { Sibolangit, Karo } \\
\text { Regency }\end{array}$ & National Park (NP) \\
\hline 19 & 02.09 .10 & $\begin{array}{l}\text { Soil + Decayed } \\
\text { Faeces }\end{array}$ & $\begin{array}{l}\text { Rhizosphere of Capsicum sp } \\
\text { (Green Chili) }\end{array}$ & $\begin{array}{l}\text { Sibolangit, Karo } \\
\text { Regency }\end{array}$ & National Park (NP) \\
\hline 20 & 02.09 .10 & Soil & $\begin{array}{l}\text { Rhizosphere of Fragaria sp } \\
\text { (strawberry) }\end{array}$ & $\begin{array}{l}\text { Sibolangit, Karo } \\
\text { Regency }\end{array}$ & $\begin{array}{l}\text { DAF (Dept. of } \\
\text { Agriculture Farming) }\end{array}$ \\
\hline 21 & 02.09 .10 & Soil & Rhizosphere of Broccoli & $\begin{array}{l}\text { Sibolangit, Karo } \\
\text { Regency }\end{array}$ & Domestic Farm (DF) \\
\hline 22 & 02.09 .10 & $\begin{array}{l}\text { Soil + decayed } \\
\text { Faeces }\end{array}$ & $\begin{array}{l}\text { Rhizospher of } \\
\text { Brassica oleracea } \\
\text { (Cabbage) }\end{array}$ & $\begin{array}{l}\text { Sibolangit, Karo } \\
\text { Regency }\end{array}$ & Domestic Farm (DF) \\
\hline 23 & 17.09.10 & Soil + decayed faeces & Rhizosphere of Ornamental Plant & Berastagi & Domestic Farm (DF) \\
\hline 24 & 17.09.10 & Soil + decayed faeces & $\begin{array}{l}\text { Rhizosphereof Brassica sp } \\
\text { (cabbage) }\end{array}$ & Berastagi & Domestic Farm (DF) \\
\hline 25 & 17.09 .10 & Soil & $\begin{array}{l}\text { Rhizosphere of Red Chili } \\
\text { (Capsicum sp) }\end{array}$ & Berastagi & Domestic Farm (DF) \\
\hline 26 & 29.0812 & Soil & Rhizosphere of Rice & Langkat Regency & Domestic Farm \\
\hline 27 & 29.08 .12 & Soil & $\begin{array}{l}\text { Rhizosphere of Oil Palm (Elaeis } \\
\text { sp) }\end{array}$ & Langkat Regency & Domestic Farm \\
\hline 28 & 29.08 .12 & Soil & Rhizosphere of Arenga & & \\
\hline 29 & 29.08 .12 & Soil & $\begin{array}{l}\text { Rhizosphere of Imperata } \\
\text { cylindrica }\end{array}$ & Langkat Regency & Domestic Farm \\
\hline 30 & 01.09 .12 & Soil & Rhizosphere of corn (Zea mays) & Langkat Regency & Domestic Farm \\
\hline
\end{tabular}

Noted *= Sumatera Utara

$* *=$ Indonesia 


\section{RESULTS AND DISCUSSION}

\section{Description of Lecanicillium lecanii} (Zimm.) Zare \& W. Gams.

Nova Hedwigia 73(1-2):10.

Basionym: Cephalosporium lecanii Zimmermann 1898 (White et al., 2005).

Isolate code : Straw_SU

Sampling Sites: Karo Regencey, Sumatera Utara Province, Indonesia

Substrate :Rhizosphere soil of Strawberry (Fragaria $\times$ ananassa Duch.)

Teleomorph : Unknown

Synonim

1. Torrubiella confragosa Mains, 1949

2. Verticillium lecanii (Zimmermann) Viégas 1939.

3. Cephalosporium lecanii Zimmermann 1898.
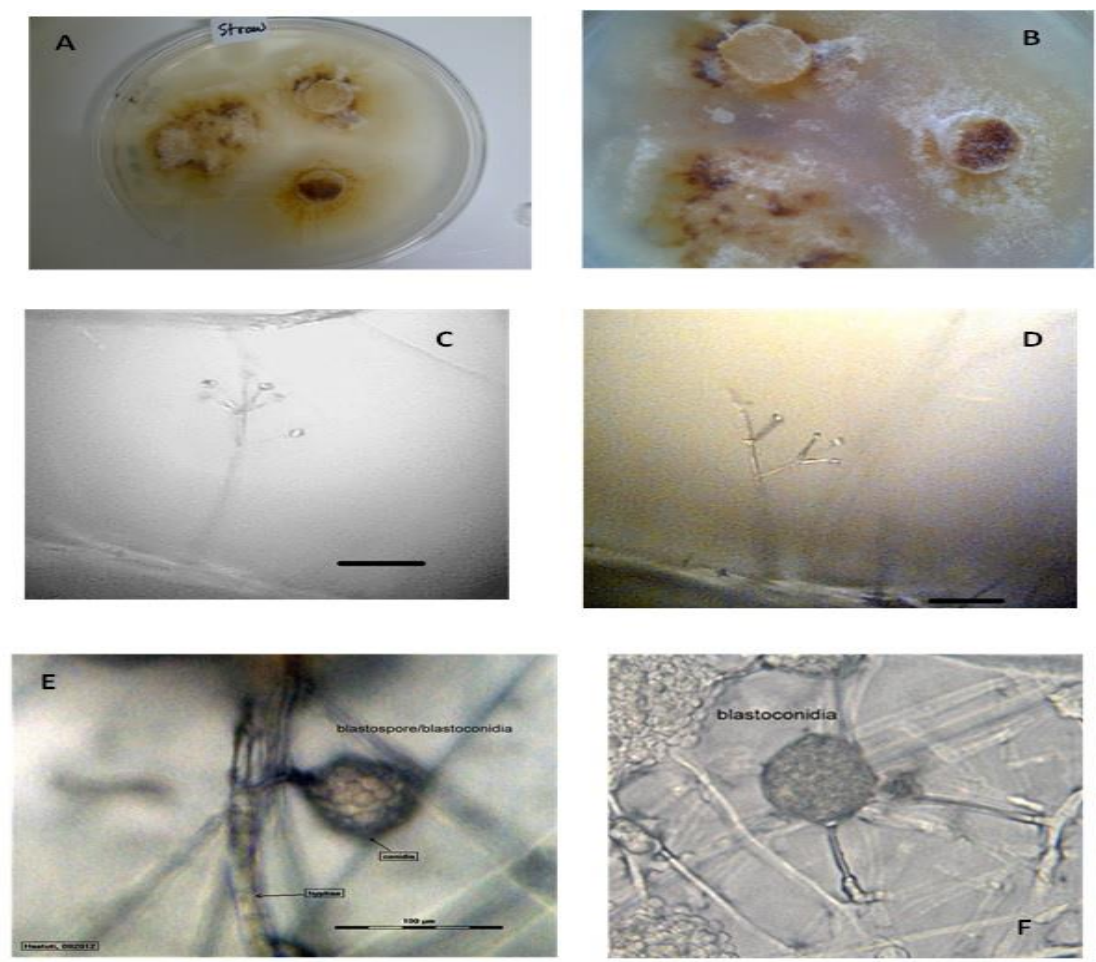

Fig.1. Morphology characteristic of Lecanicillium lecanii show the colony on the PDA and and whole body on the suface of media (bar is 10um). A \& $B$. Colony with white colour or whitish yellow or yellowish brown in mature C\&D. Conidospores form singy on phialides that arise from the conidiophore; E\&F. Blastoconidia are a particular characteristic of Leconicillium lecanii. 
Paecilomyces fumosoroseus (Wize) Brown \& Smith, Trans. Br. mycol. Soc. 40: 67. 1957 (Liang et al., 2005).

Isolate code : Areng_SU

Sampling Sites: Rhizosphere of Arenga sp

Substrate : Rhizosphere soil of Palm tree and decayed wood from Sumatera soil.

Teleomorph : Unknown

Synonim : Isaria fumosorosea

\section{Morphology Characteristics}

Colony characteristics. Colony raised up to pulvinate and rhizoid form, with powdery mature spores on the top or velvety, mycelium tufted with downy hair, compact conidiophore which fuse together and almost form a short synnemata, pinkish white to pinkish and pale purple in mature. Hyphae hyaline, septate, branched, thin and smooth-walled, 1.4-4.0 $\mu \mathrm{m}$ in diameter. Synnemata erect, simple, with naked eye seems like a thick short rod, $1.2 \mathrm{~mm}$ high, $400 \mu \mathrm{m}$ in diameter, white to pinkish white to pinkish and pinkish purple in mature. Conidiophores single or synnematous, erect, 1.6-3.6 $\mu \mathrm{m}$ in diameter, smoothwalled, hyaline, bearing flask-shaped phialides that arise singly from the conidiogenous cells on the top of conidiophore, solitary or in whorls of $2-5$, arising terminally or subterminally from the conidiophore. Phialides cells with smoothwalled, 4.8-9.1(-15.1) $\times$ 2.0-4.0 $\mu \mathrm{m}$, cylindrical and tube formed at the base and tapering toward the apical, 0.6-1.7 $\times 0.6-1.0$ $\mu \mathrm{m}$ in size. Conidia subglobose or ellipsoidal (egg-shape), smooth-walled, hyaline, (2.4-) 3.2-5.6 (-6.4) × 1.9-3.6 $\mu \mathrm{m}$ in size. Chlamydospores absent.

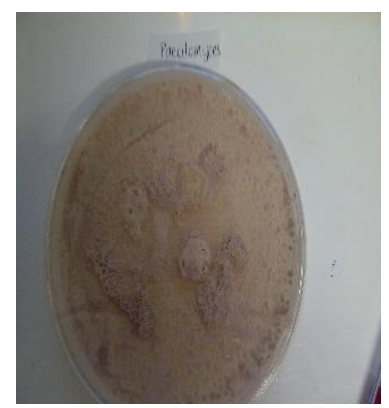

A

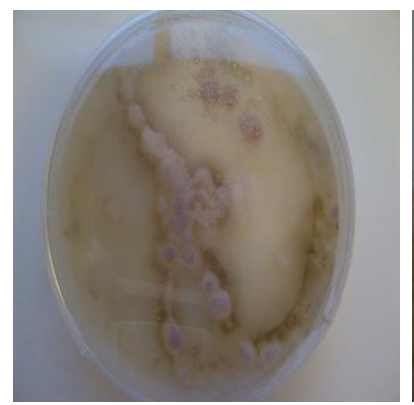

B

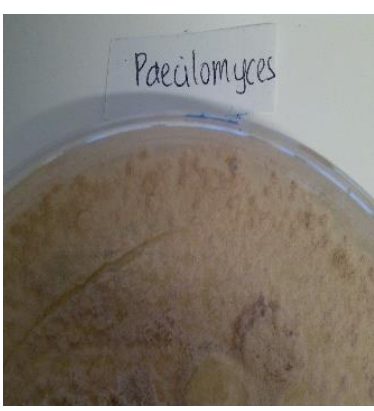

$\mathrm{C}$

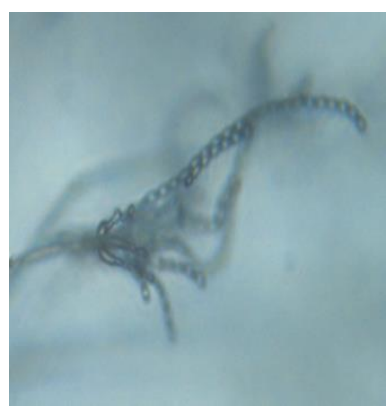

$\mathrm{D}$
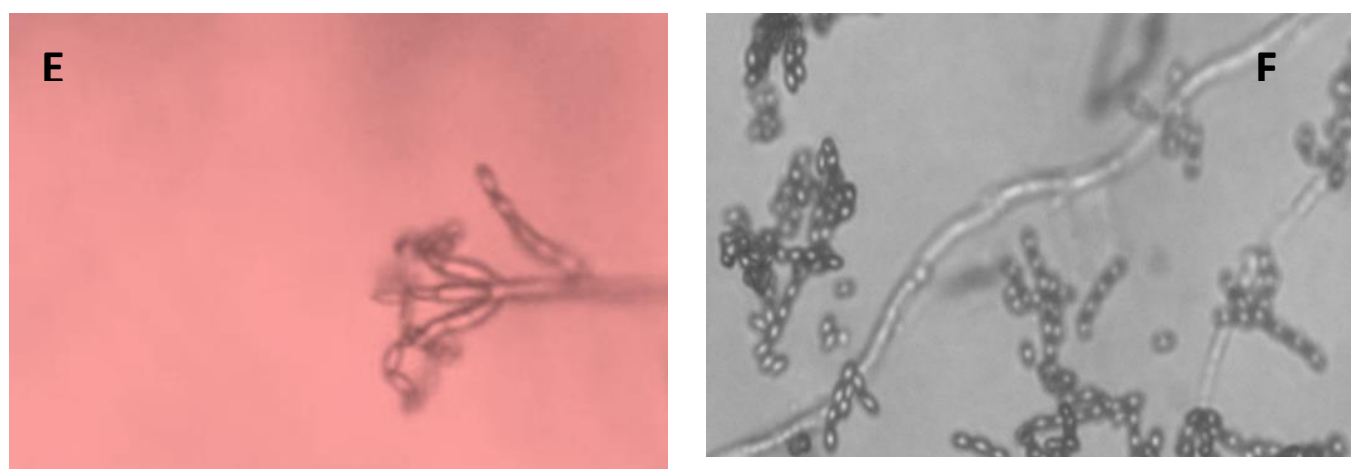

Fig 2. Paecilomyces fumosoroseus colony, and morphology show the hyphae, phialides cell, and conidia. A, B and C colony on the PDA pinkish in color to pale purple when mature; $C, D$ and $E$ show the conidiospores arising from conidiogenous cells on the top of phialides cells. Conidiospores subglobose in shape formed into a long chain. The mature conidiospore will dropped on the substrate and the new individual will grow. 
Two species from 2 genera (Paeciliomyces and Lecanicillium) of nematophagous known as entomophagous fungi were recorded from Sumatera Utara Indonesia where they were isolated from soil around vegetable field, plantation, and decayed faeces of herbivore. Soil samples from un-cultivated enviroments (Berastagi National Park, Sumatera Utara) were also tested, but there is no nematophagous found in this area. There seems to be a very low number of species diversity entmophagous fungi in soils from Indonesia.

Paecilomyces fumosoroseus infects nematode worm and kills insects with a wide host range that includes insects in over twenty five different families and many species of mites (Sandhu et al., 2012). When a blastospore of Paecilomyces fumosoroseus is spread on a suitable host, it will produce extracellular cuticle degrading enzymes and then a haustorium will penetrate to the insect's cuticle. A comparative study was made between several entomopathogenic hyphomycetes and the studies indicate Paecilomyces fumosoroseus was effective in the control of cabbage-heart caterpillar (Hashim and Ibrahim, 2003).

Lecanicillium lecanii has been proven as a potentially useful biological control agent (BCA) for soybean cyst nematode (SCN) Heterodera glycines. Shinya et al., 2008 conducted an experiment in pot trial design using $\mathrm{L}$. lecanii and it was added into the soil as a biocontrol agent to reduce infection of cyst nematode on soybean plant. The addition inoculum of L. lecanii to the soil around the root of infected plant reduced the damage due to soybean cyst nematode and also significantly supressed the egg production by cyst nematodes on the root tissue of infected plant. Based on research by Shinya et al., 2008, we the potential of L. lecanii should be considered as an alternative to overcome the problem especially caused by plant pathogen nematodes.

\section{Future Work}

Future work need to be done using those fungi in bioassay pot trial design to know their effectiveness in control root knot nematode on soma economically important plant species.

\section{REFFERENCE}

Brownbridge M, Humber RA, Parker BL, Skinner L. Fungal entomopathogens recovered from Vermont forest soils. Mycologia. 1993;85:358-361.

Duddington C L. 1955. Notes on the Technique of Handling Predacious Fungi. Trans. Brit. Mycologia. Vol. 38, Part 2, 97-103 (1955).

Hajek AE, Shimazu M, Knoblauch B. Isolating a species of Entomopthorales using resting sporebearing soil. J. Invertebr. Pathol. 2000;75:298-300.

Jafee H P. 1996. Soil Microcosms and the Population biology of Nematophagous Fungi. Ecology 77:690-693.

Larsen M. 1998. Biological Control of Helminths. Dants Center for Experimental Parasitology, Royal Veterinary and Agricultural University. Denmark. Int. Jour. Parasitology. 29: 139-146.

Liang Z Q, Y F Han, H L Chu and A Yi Liu. 2005. Studies on the genus Paecilomyces in China. I. Fungal Diversity 20: 83-101.

White J F, C W Bacon, N L H Jones, W Spatafora,. 2005: Clavicipitalean Fungi. Evolutionary Biology, Chemistry, Biocontrol Impacts. Mycology. Vol. 19.530p.

Merilon J M and K G Ramawat. 2012. Plant Defence: Biological Control. Progess in Biological Control. Springer.

Tuininga A R, J L Miller, S U. Morath, T J Daniels. R C. Falco, M Marchese, S Sahabi, D Rosa, K C. 2009. Isolation of Entomopathogenic Fungi From Soils and Ixodes scapularis (Acari: 
Ixodidae) Ticks: Prevalence and

Methods. J Med Entomol. 2009 May;

46(3): 557-565. 